\title{
Philippine Basic Education Learning Continuity Plan: Creating Space for Indigenous Peoples toward Inclusive post-COVID-19 Education
}

\author{
Michael Bobias Cahapay ${ }^{1 *}$ [
}

${ }^{1}$ Mindanao State University, General Santos City, PHILIPPINES

*Corresponding Author: mbcahapay@up.edu.ph

Citation: Cahapay, M. B. (2021). Philippine Basic Education Learning Continuity Plan: Creating Space for Indigenous Peoples toward Inclusive post-COVID-19 Education. International Journal of Pedagogical Development and Lifelong Learning, 2(1), ep2102. https://doi.org/10.30935/ijpdll/9294

\begin{abstract}
The continuity of education after the current crisis is a major national concern. A vulnerable group that may be further marginalized in the process consists of learners in indigenous communities. Through a review of the Philippine Basic Education Learning Continuity Plan (BE-LCP), this article seeks to create space for the indigenous peoples (IP) learners toward an inclusive post-coronavirus disease 2019 (COVID-19) education. Considering the preCOVID-19 background of resources and the current epidemiological status of IP communities, the researcher presents strategies on how post-COVID-19 education can be delivered. For example, in an IP community with electricity access and low technology access but no internet and has high to moderate risk of virus infection, a combination of print modular learning and television- and radio- based learning can be adopted but not the synchronous and asynchronous learning and stagger in-person learning. This suggested option and others are offered in the paper.
\end{abstract}

Keywords: learning continuity plan, indigenous peoples, COVID-19 pandemic, inclusive education, Philippines Received: 2 Aug. 2020 Accepted: 22 Sep. 2020

\section{INTRODUCTION}

Since the COVID-19 global outbreak early this year, a billion children and youth were affected by the school closures across the world. At the front of further inequality in education amid the crisis are the vulnerable groups that include the IP learners. Thus, aside from finding a solution to how education can be reshaped, there is a further need to look at how it could be made inclusive for the many marginalized IP learners.

The Global Education Coalition launched by the United Nations Educational, Scientific, and Cultural Organization (2020) aims to facilitate universal and equitable educational opportunities for children and youth amid the current emergency educational interruption. Through its multilateral partners, it underscored the need for efficient and collaborative support to countries to lessen the unfavorable impacts of the situation. At the core of this effort are the most disadvantaged groups such as the IP learners.

In the Philippines, the IPs account for at least eleven million of the national population. They may be classified under eight major groups. The Lumad IP groups and the Cordillera IP groups form a significant portion. Other distinct indigenous groups include the Negrito IP groups, Visayas IP groups, and Islamic IP groups (Foundation for the
Philippine Environment, 2013). They have a reported low literacy rate (De Vera, 2007) due to restricted access to education and this problem is exacerbated by the present COVID-19 crisis (Chavez, 2020).

As a response to the need to continue education amid the restrictions posed by the COVID-19 crisis, the Philippines through the Department of Education (2020) collaboratively developed the BE-LCP for the school year 2020-2021. The said plan is the outcome of different consultative activities. There were discussions with education stakeholders such as legislators of the house and senate committees on basic education, executives from the different units and field offices of the department, and the general community. A series of online surveys of more than 700,000 respondents such as parents and learners as well as teachers on their readiness for remote education were also conducted. A further analysis of data on basic education as well as the epidemiological status was also considered. The inputs from the discussions, surveys, and analyses were unified in planning the framework.

Aside from the essential requirements of education such as the most essential learning competencies and required protocols in schools, the plan importantly covers multiple learning delivery modalities. While it underscores equity considerations for all possible circumstances in that aspect, the researcher asserts that there is a need to further contextualize it. There has been an order to adapt the plan down to the regions 
(Department of Education, 2020). However, this need presents another challenge to carefully reconsider education with special consideration on the distinctly disadvantaged IP learners.

Finding ways on how education can be delivered to the vulnerable group of IP learners amid the COVID-19 crisis is important so that appropriate learning delivery modes can be carefully contextualized from any learning continuity plan. If options of learning delivery modes can be offered based on their distinct contexts, it may guide education officials, school administrators, and teachers in making decisions to reshape education amid the COVID-19 crisis. Aside from those intentions, safeguarding the right to education of IP learners who may have been already disadvantaged is a primary concern in this age when inclusive education is a must with or without the COVID-19 crisis.

Thus, by reviewing the Philippine BE-LCP, this article seeks to create space for the IP learners toward inclusive post-COVID-19 education.

\section{PRE-COVID-19 BACKGROUND OF RESOURCES OF IP COMMUNITIES}

Two of the resources that are deemed important in reconsidering education in the post-COVID-19 period are electricity access and technology access. These two resources usually pose a great challenge in remote places. The IP settlements are usually located in remote parts of the country (De Vera, 2007) and though there are no past records specifically accounting for the electricity access and technology access in IP communities, reports and studies offer a glimpse.

As of a recent report, the number of homes without electricity access in the country is around 2,319,660 (Peralta, 2017). This number did not significantly decrease in the following year as there are still around 2,399,108 homes that have no electricity access. Of this number, 529,952 are in Luzon, 524,040 are in the Visayas, and 1,345, 116 are in Mindanao (Tamayo, 2018). These figures do not indicate if these homes belong to the IP communities. However, it should be noted that Mindanao, where the largest number of homes without electricity access can be found, is also the home to the sizable population of IP communities.

On the other hand, in terms of technology access, Microsoft Philippines Communications Team (2018) contends that the majority of the IP groups in remote locations have restricted technology access. This seems supported in the work of Roberts and Hernandez (2019). Just focusing on the dimensions of availability and affordability, they stated that the level of technology access in the country in terms of connectivity often mirrors geographical and financial marginalization. They expressed that the IP group in the rural community is one of the groups from which connectivity is often not available. And though technology access may be available, it may be expensive for them on a low income.

The quality of electricity access and technology access has an implication on the current options one can select for the post-COVID19 education for IP learners. Some modalities of learning delivery can or cannot be possible with or without access to one of these two resources. Thus, by looking into these resources in an IP community, cogent decisions may be better arrived at.

\section{CURRENT COVID-19 EPIDEMIOLOGICAL STATUS OF IP COMMUNITIES}

Another important consideration that must be noted in reshaping education in the post-COVID-19 period is the epidemiological status of the IP communities. This factor is crucial because, after all, the health safety of the learners is an utmost concern before anything else. IP concentrations are often situated in secluded areas of the country (De Vera, 2007) and though no current data particularly suggest that an IP community is more or less safe from the virus, the epidemiological status of the regions of an IP community suggests its level of safety.

According to Google Search Help as of November 23, the National Capital Region $(195,000+)$ recorded the highest number of confirmed positive cases of COVID-19 infection followed by Calabarzon $(76,794)$, Central Luzon $(26,031)$ and Central Luzon $(25,115)$. These regions with a high risk of COVID-19 infection have a low concentration of IP communities with less than one million (Foundation for the Philippine Environment, 2013).

On the other hand, regions that recorded a low number confirmed positive cases of COVID-19 infection were Ilocos $(3,777)$, Cagayan Valley $(3,760)$, Caraga $(3,484)$, and Mimaropa $(2,530)$. It should be noted that the first two regions with low risk COVID-19 infection are also identified to have a high concentration of IP population with over one million each while the last two regions have close to one million each (Foundation for the Philippine Environment, 2013).

Considering the epidemiological status of an IP community is important in making decisions about what option of learning delivery mode is feasible. The no, low, moderate, or high risk of COVID-19 transmission must be considered in making decisions about what learning delivery is possible such that the health of the learners can be secured.

\section{POST-COVID-19 EDUCATION FOR IP LEARNERS}

Table 1 presents the options for proposed post-COVID-19 education. It shows the pre-COVID background of resources and current COVID-19 epidemiological status of each IP community. Then, corresponding suggested learning delivery modes are offered.

For example, in option 3, in an IP community with electricity access and technology access but no internet and has high to moderate risk of COVID-19 infection, it is practically suggested that a remote learning approach combining print modular learning and television- and radiobased learning will be the safest option.

These strategies are described as follows..

Print modular learning. This remote learning delivery mode uses the print module. A module is an instructional material that includes information about a topic, focus on learning activities, and culminate in some assessment to demonstrate understanding (Sweet, 2020). It is the only learning delivery mode that is feasible in all six options presented above which was also recently reported to be the most preferred option for learners in the country (Abad, 2020).

This mode seems to be favored because it does not necessarily require electricity access nor technology and internet access. It is also the safest learning delivery mode whether an IP community is tagged as 
Table 1. Proposed Post-COVID-19 Education for IP Learners

\begin{tabular}{|c|c|c|c|c|}
\hline \multirow[b]{2}{*}{ Option } & \multirow{2}{*}{$\begin{array}{l}\text { Pre-COVID-19 Background of } \\
\text { Resources }\end{array}$} & \multirow{2}{*}{$\begin{array}{c}\text { Current COVID-19 } \\
\text { Epidemiological Status }\end{array}$} & \multicolumn{2}{|c|}{$\begin{array}{lc}\text { Post COVID-19 Education } \\
\end{array}$} \\
\hline & & & $\begin{array}{c}\text { Suggested Learning Delivery } \\
\text { Mode }\end{array}$ & Specific Learning Delivery Mode \\
\hline 1 & $\begin{array}{l}\text { No electricity access, no technology, } \\
\text { and no internet access }\end{array}$ & High to moderate risk & Remote learning & -Print modular learning \\
\hline 2 & $\begin{array}{c}\text { No electricity access, no technology, } \\
\text { and no internet access }\end{array}$ & Low to no risk & Blended learning & $\begin{array}{l}\text {-Stagger in-person learning } \\
\text {-Print modular learning }\end{array}$ \\
\hline 3 & $\begin{array}{l}\text { With electricity access, with low } \\
\text { technology, and no internet access }\end{array}$ & High to moderate risk & Remote learning & $\begin{array}{l}\text {-Print modular learning } \\
\text {-Television- and radio- based learning }\end{array}$ \\
\hline 4 & $\begin{array}{l}\text { With electricity access, with low } \\
\text { technology, and no internet access }\end{array}$ & Low to no risk & Blended learning & $\begin{array}{c}\text {-Stagger in-person learning } \\
\text {-Print modular learning } \\
\text {-Television- and radio- based learning }\end{array}$ \\
\hline 5 & $\begin{array}{l}\text { With electricity access, with high } \\
\text { and low technology, and with } \\
\text { internet access }\end{array}$ & High to moderate risk & Remote learning & $\begin{array}{c}\text {-Print modular learning } \\
\text {-Television- and radio- based learning } \\
\text {-Synchronous and asynchronous learning }\end{array}$ \\
\hline 6 & $\begin{array}{l}\text { With electricity access, with high } \\
\text { and low technology, and with } \\
\text { internet access }\end{array}$ & Low to no risk & Blended learning & $\begin{array}{c}\text {-Stagger in-person learning } \\
\text {-Print modular learning } \\
\text {-Television- and radio- based learning } \\
\text {-Synchronous and asynchronous learning }\end{array}$ \\
\hline
\end{tabular}

low or high risk of virus infection. It does need, however, a great amount of direct supervision from an adult or a parent, especially for the younger learners.

Television- and radio- based learning. Another remote learning delivery mode is television- and radio- based learning. This remote learning delivery mode using low technologies has been recently applied in the remote parts of a country in which students learn lessons via radio and television at their homes (Omar, 2020). Given that the country has well established traditional broadcast media networks, this mode will complement efforts in using digital programs to deliver instruction (Arcilla, 2020).

It requires electricity access and low technologies such as television and radio, which could be common in IP communities nowadays; but such an option does not necessarily need internet access. It is also a safe learning delivery mode in situations of a low or high risk of virus infection. It demands a minimal amount of direct supervision from an adult or a parent, especially for older learners.

Synchronous and asynchronous learning. It is also a remote learning delivery mode in which teaching may be delivered and learning may occur online using high technologies. Synchronous learning can be done online via live lectures, instant messaging, and virtual classrooms while asynchronous learning may occur through blog readings, recorded videos, or discussion boards (Lawless, 2020). However, a new survey reported that most students in the country least prefer online learning (Hernando-Malipot, 2020).

Synchronous and asynchronous learning requires electricity access and technology and internet access, which may not necessarily be available in most IP communities. On the other hand, just like the first two learning delivery modes, it safe for the learners. It needs a moderate amount of supervision from an adult or a parent for younger learners and minimal for older learners.

Stagger in-person learning. A face-to-face learning delivery mode is the stagger in-person learning in which the teacher and learners are present in a physical learning space. However, the time element is modified in which, for example, half of the learners of a class will attend from Monday to Tuesday, then the other half from Thursday to Friday (Melnick et al., 2020). The classes may be done in classrooms that are spacious enough or other spaces such as gymnasium and playground (Kingsley, 2020).

It appears to be a favorable option because it does not require electricity access nor internet access which are both real challenges in many IP communities. It should be noted, however, that given the current national policy that no face-to-face classes shall be allowed, stagger in-person learning can only be conservatively adopted at least after a consistent zero infection history in the IP community sooner.

\section{CONCLUSION}

The BE-LCP was collaboratively developed as a noble response to the challenges posed by COVID-19 in the Philippine basic education. While it underscores equity considerations, there is a need to further contextualize the plan to the multifaceted situation of a disadvantaged segment of learners. Thus, through a review of the plan, this paper was guided by the purpose to create space for the IP learners toward inclusive post-COVID-19 education.

Looking into the pre-COVID-19 background of resources and the current epidemiological status of the IP communities, this paper offered possible learning delivery modes. These possible learning delivery modes include print modular learning, radio- and television- based learning, synchronous and asynchronous learning, and stagger inperson learning.

The BE-CLP has a magnanimous cause to continue basic education amid the present crisis. If it will be further adapted to be responsive, appropriate, and relevant to the unique condition of the IP learners and their communities, it will not only serve as a short-term answer to the difficulties of the current situation but also a long-term solution to the call for inclusive education. It presents a timely gesture of contribution to the global quest to attain education for all.

\section{REFERENCES}

Abad, M. (2020, July 02). Printed materials, online classes 'most preferred' for distance learning - DepEd. Rappler. Retrieved from https://rappler.com/nation/ 
Arcilla, J. (2020, April 21). DepEd eyes TV, radio lessons. The Manila Times. Retrieved from https://www.manilatimes.net/2020/04/21/ news/national/

Chavez, L. (2020, April 03). For Philippines' displaced indigenous students, COVID-19 is one of many threats. Mongabay. Retrieved from https://news.mongabay.com/

De Vera, D. E. (2007). Indigenous Peoples in the Philippines: A country case study. Presented at the RNIP Regional Assembly Hanoi, Vietnam. Retrieved from http://www.iapad.org/wpcontent/uploads/

Department of Education (2020). DepEd Basic Education Learning Continuity Plan in the time of COVID-19. Retrieved from https://www.teacherph.com/

Foundation for the Philippine Environment (2013). Where are Indigenous Peoples Distributed in the Philippines? Retrieved from https://fpe.ph/indigenous-communities.html/view/

Hernando-Malipot, M. (2020, July 03). DepEd: Most students prefer 'modular' learning over online. Manila Bulletin. Retrieved from https://mb.com.ph/

Kingsley, P. (2020, April 17). In Denmark, the rarest of sights: Classrooms full of students. New York Times. https://www.nytimes.com/2020/04/17/world/europe/

Lawless, C. (2020, April 23). Synchronous vs asynchronous learning: Which is right for your learners? LearnUpon. Retrieved from https://www.learnupon.com/blog/
Melnick, H., Darling-Hammond, L., Leung, M., Yun, C., Schachner, A., Plasencia, S., \& Ondrasek, N. (2020, May 15). Reopening schools in the context of COVID-19: Health and safety guidelines from other countries. Learning Policy Institute. Retrieved from https://learningpolicyinstitute.org/product/

Microsoft Philippines Communications Team (2018). Empowering the indigenous learners in the Philippines through education. Retrieved from https://news.microsoft.com/en-ph/

Omar (2020, April 21). Afghan students move to remote classes to fill gap caused by coronavirus. Salaam Times. Retrieved from https://afghanistan.asia-news.com/

Peralta, J. (2017, August 27). Over 2.3 million households remain without electricity - NEA. CNN Philippines. Retrieved from https://www.cnn.ph/news/

Roberts, T., \& Hernandez, K. (2019). Digital access is not binary: The 5'A's of technology access in the Philippines. The Electronic Journal of Information Systems in Developing Countries, 85(4), 1-14. https://doi.org/10.1002/isd2.12084

Sweet, K. (2020). What is an educational module? Classroom. Retrieved from https://classroom.synonym.com/

Tamayo, B. (2018, March 28). 2.4-M households are still without electricity - senator. The Manila Times. Retrieved from https://www.manilatimes.net/2018/03/28/news/national/

UNESCO (2020). COVID-19 education response. Retrieved from https://en.unesco.org/covid19/educationresponse/globalcoalition 